\title{
Regeneration time: ancient wisdom for planetary wellbeing
}

\author{
Anne Poelina ${ }^{1,2}(\mathbb{D})$, Sandra Wooltorton ${ }^{1,3 *}(\mathbb{D})$, Mindy Blaise ${ }^{3}$ (D) , Catrina Luz Aniere ${ }^{4}$, \\ Pierre Horwitz ${ }^{3}$ (D), Peta J. White ${ }^{5}$ (i) and Stephen Muecke ${ }^{1,6}(\mathbb{D}$ \\ ${ }^{1}$ Nulungu Research Institute, The University of Notre Dame Australia - Broome Campus, Broome, WA, Australia, \\ ${ }^{2}$ Water Justice Hub, Australian National University, Canberra, ACT, Australia, ${ }^{3}$ Strategic Centre for People, Place and \\ Planet, Edith Cowan University, Joondalup, WA, Australia, ${ }^{4}$ Millennium Kids, Perth, WA, Australia, ${ }^{5}$ School of \\ Education, Deakin University, Burwood, VIC, Australia and ${ }^{6}$ Environmental Humanities, University of New South Wales, \\ Sydney, NSW, Australia \\ *Corresponding author. Email: sandra.wooltorton@nd.edu.au
}

(Received 16 November 2021; revised 11 December 2021; accepted 13 December 2021; first published online 24 January 2022)

\begin{abstract}
In these regenerative times prompted by the Anthropocene, Aboriginal voices are situated to draw on ancient wisdom for local learning and to share information across the globe as ecological imperative for planetary wellbeing. In this paper, postqualitative research foregrounds the sentient nature of life as ancestral power and brings the vitality of co-becoming as our places into active engagement. It enables coloniality to surface and reveals how it sits in our places and lives, in plain sight but unnoticed because of its so-called common sense. Postqualitative research relates with ancient knowledges in foregrounding Country's animacy and presence, revealing the essence of time as non-linear, cyclical and perpetual. In this way, we are places, weather and climate, not separate. Postqualitative research also relates with ancient knowledge in illustrating Country as agentic and time as multiple, free of constraint and directly involved in our everyday. Country is active witness in the lives of Aboriginal peoples, here always. This is a strong basis for decolonisation. We all have a responsibility to listen, to help create a new direction for the future in the present time.
\end{abstract}

Keywords: postqualitative research; ancient wisdom; planetary wellbeing; decolonial; Aboriginal philosophy; animacy

\section{Opening}

We acknowledge the Elders and Traditional Owners of three Western Australian language regions: the southwest comprising Noongar Boodjar, east to Ngadju Country of the Great Western Woodlands, and the Nyikina nation of the Martuwarra Fitzroy River in the Kimberley. We particularly acknowledge Betty Logan, Ngadju elder of wisdom and vision who co-leads a Ngadju family regenerative learning program that is involved in this research.

In this conceptual paper, we work within a relational, postqualitative, decolonial paradigm for environmental education - and life - with ancient wisdom at its heart. We inquire into regenerative cultures; where people recognise their extended participation can co-create possibilities for thriving collaborative futures (Wahl, 2016). Using field philosophy (Buchanan, Bastian \& Chrulew, 2018; van Dooren, 2018) we take a katitjin bidi or learning journey, to interweave poetry and reflective narratives with wisdom of three Aboriginal ${ }^{1}$ languages: Noongar (southwest), Nyikina (one of the eight Martuwarra nations) and Ngadju (Great Western Woodlands). 
Katitjin bidi is Noongar, meaning knowledge path, and is also a metaphor for connecting people, place and time.

Today, global environmental changes are central matters of concern, with demands for climate care (IPCC, 2021), species respect (Díaz et al., 2019), recognition that the cry of the earth and the cry of the poor are the same (Pope Francis, 2015), and acknowledgement that human and planetary wellbeing are directly connected (Jenkins, Horwitz \& Arabena, 2018; Tollefson, 2020). Life can never be what it was. We accept this challenge, while asking, as environmental educators, how we can co-create this new direction. How do we, as humans, extend our sense of society to include the agencies of non-human beings and places? How do we understand the requests of our non-human kin in this reconceived polity, while taking the necessary time for co-becoming? What do we mean by we are a part of, not apart from, our environment?

Our intention is to connect, reconnect, heal and recreate linkages celebrated since the dawn of time. We refer to our multispecies family members as kin, rather than he/she/it (Kimmerer, 2017), which grounds each relationship within a universally inclusive environment. Through our katitjin bidi we celebrate values and ethics of care and creativity, narrative, lived experience, the collective, justice, and ways of responding to sentient, animate places. We particularly attend to notions of non-linear time. By 'river', we mean to include riverine multispecies communities, surface and subsurface living water flows as part of cycles, agential actions and socio-cultural interpretations (RiverOfLife, Taylor \& Poelina, 2021).

As per the NAIDOC $2021^{2}$ theme, Healing Country means embracing First Nations' cultural knowledge and understanding of Country as beyond Australia's national heritage, but as first 'world heritage and world culture' (United Nations, 2011). It means truth telling about our past, and redressing continuing environmental colonialism and injustice (Poelina, Brueckner \& McDuffie, 2020). Healing Country is healing for all Australians. It is healing from the trauma of continual colonial restrictions. Since time immemorial, as Australians our responsibility and our response-ability (Bawaka Country et al., 2019), has been to care for place, its histories and its stories. In this paper, we address the question of how this healing standpoint is reciprocal and restorative. We consider how to embed it in the heart of Australian environmental education.

We begin with context ${ }^{3}$ to explain concepts such as past presences, deep co-becomings and a sense of the long now, the waiting time. Then we explore stories of the djenark (seagull) of Derbal Yerrigan (the Swan River), pre-colonial stories of Wadjemup (renamed Rottnest), notions of the ngama (waterhole) carers of the Great Western Woodlands, recognising the shimmer of life, and accounts of Martuwarra (the Fitzroy River) that sustains reciprocal Aboriginal economies and ethics of care. Finally, we describe regenerative futures, where places share in co-creation, in caring and in generating meaning.

\section{Context}

We begin our katitjin bidi in our university libraries. We begin with Williams' (2019) work on decolonisation through the language of the Land ${ }^{4}$ as the basis for a decolonising paradigm. She contends that we need to broaden the conversation from Indigenous people's human right to their language, because Indigenous languages and wisdom are an ecological imperative for planetary wellbeing, to "bring the world into presence" (Williams, 2019, p. 176). She shows how places and flows such as water are living, animate and agentic. Using Williams' (2019) work, we understand that Indigenous peoples' relations to lives, languages and lands are critical to decolonisation efforts. This includes the reindigenization of those no longer indigenous to place, a learning process. Indigenous languages and the knowledge systems they carry are essential to maintain practices integral to the ecological requirements of their places; a fact unknown or overlooked by Western and institutional forms of power. Decolonisation, therefore, relies upon strengthening of Indigenous realities, rights and languages, for the future of humanity. 
Next we explore postqualitative research (Muecke \& Roe, 2020; van Dooren, 2018) as part of a decolonising paradigm: a field philosophy for the journey. First, we need to explain our understanding of postqualitative after Barad's clarification of posthumanism (Barad \& Gandorfer, 2021, p. 19). It is not to exclude qualitative research as if a binary either/or, but to rework and extend qualitative research, making it more inclusive of previously unnoticed or excluded phenomena. In our case, we use it to foreground our relationship with Country. This explains our use of postqualitative rather than post qualitative.

\section{Postqualitative research as part of a decolonial paradigm}

Nyikina leader Paddy Roe taught that 'things must go both ways' (Morrissey, 2019, pp. 105-6), referring to exchange in general, including teaching. This bidirectionality contradicts the idea of the spread (and imbuing) of knowledge, an idea assumed by the tendency for modernising knowledges from Europe and North America to universalise themselves. All knowledges aspire to more universal relevance, but certain valve-like practices in colonising movements of people, wealth and knowledge block 'both way' exchanges. Indigenous knowledge that is useful and relevant to the modernising invaders is taken up, but much less is returned. Thousands of these valves kept popping up to keep local knowledges local, while feeding the spread of modern sciences and social sciences across Indigenous Countries. Translating everything into English is one such valve, so too is the colonial practice of anonymously calling holders of Indigenous Intellectual Property 'informants', so too is the priority of numerical data. The modern sciences and social sciences were thus able to continue the universalising mission they had started in Europe. Today, this situation is changing somewhat with the possibility for sharing Indigenous sciences globally, among Indigenous peoples. Taking the relational modern sciences as central, field philosophy advocates negotiation among knowledge 'traders' revalorising place-based situated knowledges in Donna Haraway's sense of situated (1988) and also following Nakata's 'Indigenous standpoint theory' (2007).

The literature on post humanist and postqualitative research often acknowledges Indigenous knowledges and cultures as ways of thinking before and beyond the historical bracket that was the development of European post-enlightenment humanism (Bignall, Hemming \& Rigney, 2016). That version of modernism and modernisation had powerful universalising tendencies, as it succeeded, after successive waves of imperialism, in installing itself as a global hegemon, one only given pause by recent climate change and related crises.

In that pause, a new opportunity and a new respect for Indigenous 'Earth wisdom' has emerged. However, this is not without hundreds of years of violent struggles by Indigenous protectors of country resisting the extractive and exploitative practices and logics of colonisation (RiverOfLife Martuwarra, McDuffie \& Poelina, 2020). The imperial spread of modernist and modernising practices, out from their European 'provinces' (Chakrabarty, 2007) with their progressive script of making life better for everyone, was powerful and pervasive in a global world without limits. It was a set of mobile cultures that did not listen to those tied to their territories for good ecological reasons; living on them, not from them. The decline of carbon acceleration, the uptake of more sustainable energy sources, and new-found territorial foci, have brought Indigenous knowledges into serious contention, both politically and scientifically. That Indigenous communities across the globe have been able to form alliances is a sign of the potential universalisation of their counter-imperial, coupled with sustainable, strategies. Indigenous peoples are often able to agree on principles (with potential for universalisation) to do with attending to what people know, after millennia of experience, each territory can sustain, according to its subjective attributes (Whyte, 2018).

For the following sections, we need to critique 'rationality', and its separations of mind from body, mind from spirit and head from heart. Concepts such as independence, a human/nature split and rationality itself, are only possible in contexts of artificial exclusion and discounting, 
ultimately stripping the earth of poetic inclusion with its dominant narrative of human exceptionalism. This is only one of many human stories. At this point in species loss and climate changing scenarios, other stories can be more useful (Mueller, 2017; Whyte, 2018). The challenge is to see and become differently but in order to do this we may need to consider 'seeing with our ears and listening with our eyes' (McDuffie \& Poelina, 2018).

\section{Life as deeply relational}

There is a growing body of researchers such as the Gay'wu Group of Women (2019); Poelina (2021); Riley and White (2019); Graham (2008, 2014) and Mueller (2017) who understand life as deeply inter-relational. Their work links people, places and stories - and attends through attuning and understanding the meaning of the story and then considering how to act through values and ethics towards human and non-human kin (Nangan \& Edwards, 1976). For instance, Riley and White (2019) seek to hold contrasting and conflicting stories together, calling in different logics for use and sharing.

From a relational standpoint we recognise ourselves as embedded and situated where we are co-becoming with place, reducing the boundary between human and non-human, and object and subject (Barad, 2007). Relational pedagogies move away from assigning discursive narratives to human-centric experiences with/of/on place, towards a grounded, lived, embodied, inquiry into how the body responds through affective seeking of vibrancy and liveliness. We draw from different disciplines and knowledge systems, using branches of philosophy, science, and arts: making connections across practices and destabilizing habits of thought. This challenges linear realisations about/of place that use technicist, mechanistic, and instrumentalist ways of acquiring knowledge. Instead, we learn that time is situated and cyclical, and we learn to wait, watch and participate.

\section{Feeling and hearing country}

We build upon the work of Poelina, Wooltorton, et al. (2020), who show how Nyikina and Noongar cultural rules embed people within relational ecologies of place and ensure the engagement of people with their home-places. This relationship is respectful and reciprocal, grounded in an ethics of care towards all living beings and living systems. As a kincentric ecology, a notion of place reflects a living, storied, relational world that is nurturing, fertile, alive and inclusive of all beings (Milgin, Nardea, Grey, Laborde \& Jackson, 2020). A kincentric ecology is to understand oneself as part of an ecological family with shared Country and ancestry. Country is an Aboriginal concept for inclusive living, where vibrant ecosystems are mutually responsive through spiritual and intuitive feelings such as wirrin (Noongar) and liyan (Nyikina).

\section{Time is co-becoming}

In this decolonising paradigm, time is relational in that it co-emerges with clouds, rain, weather, seasons, rivers, ecosystems and people. English language portrays time as merely a linear, standalone concept in which we banish the past to 'the past' (Bawaka Country et al., 2020). However, this denies the richness of the present, which is inclusive of the past in knowledge, memories, repeated actions and habits, and constantly allows for the eventualities of the future. A linear, narrow view of time ignores historical injustices ('the past is the past') and denies the continuing invasive unjust developments such as extractive colonisation of Indigenous Lands and Waters (Poelina, Brueckner \& McDuffie, 2020). It enables imaginings of a fictitious present built on denial - of injustice, climate change, pandemics, poverty and the need for social and behaviour changes. Rather, the non-binary concept of co-becoming offers a way of learning to understand time as complex and interrelated, as this explanation shows: 
Co-becoming is our conceptualization of a Bawaka Yolngu ontology within which everything exists in a state of emergence and relationality. Not only are all beings - human, animal, plant, process, thing or affect - vital and sapient with their own knowledge and law, but their very being is constituted through relationships that are constantly re-generated. We argue that more-than-humans and humans co-become as place/space, in deep relation to all the diverse co-becomings that also constitute it. Space/place is its doings, its beings, its knowings, its co-becomings. (Bawaka Country et al., 2016, p. 456)

Using this logic, we utilise the ethical notion of response-ability, the ability to respond to an agential, living, emotional landscape through our relationships, reciprocity and senses. These response-abilities are diverse, multi-layered, storied and unending. We co-become with place, while continuously attending to, recognising, and responding to our human and more than human place relations. "Both the past and the future are contained inside every moment, in an undoing of inside/outside. So this is clearly not a notion of space and time in the usual sense" (Barad \& Gandorfer, 2021, p. 44).

In a recent article Bawaka Country et al. (2020) show how during actions like walking to homeland as the clouds gather for the wet season, our entangled place relationships co-become with/in time as weather and Country. In this way across the seasons we co-become with perpetual patterns of weather over time - we become related, not separate. By perpetual we mean in the sense that there are always patterns, although they may change over time - like climate. Rather than linear, colonised and constrained, time is multiple, communicative and agential, told and revealed by more than human agencies. In this relational view we are climate, connected as kin, and our nourishing actions with Country shapes our co-becomings. This is decolonial in the sense that we are constantly attending, attuned and have response-ability in time when the past is co-present (Bawaka Country et al., 2019). It is about justice when we trace the entanglements (Barad \& Gandorfer, 2021). Just as we are climate, we recognise that injustice is found by tracing relationships. Therefore, climate justice is to decolonise, to reindigenise, to act with the lively agents now perceptible through participation.

\section{Shimmer: ancestral power}

Bird Rose (2017) describes the ancestral power of life as shimmer, a process of encounter and transformation requiring an ethic of kinship and care. She builds upon work of Stengers (2010) and Morphy (1989) and writes that,

Shimmer is an Aboriginal aesthetic that helps call us into these multispecies worlds. I use the term "aesthetic" in a nontechnical way to discuss things that appeal to the senses, things that evoke or capture feelings and responses. I want to think of aesthetics, in part, in angiosperm terms, that is, in terms of lures that both entice one's attention and offer rewards. (Bird Rose, 2017, p. G53)

She says shimmer is one's capacity to see and experience ancestral power. However, for something to shimmer and catch one's eye there must also be no shimmer. Shimmer comes with the pulse of season change, and the shininess and health of new growth, new generations. Shimmer might also be a pattern, or a dance, or a piece of art. It is the love story between species, such as the lure felt by the flying foxes to the angiosperms. It is the flourishing of life. It feels tragic to witness shimmer, when we trash life (Bird Rose, 2017).

\section{River science: what is a river?}

Rivers have and hold memories, across and with time. Their own stories, long shared with socioecological communities over space-times are ever-present, ever past and always co-becoming 
(Bawaka Country et al., 2019). The paradox of rivers is that they are water of the land. Water and rocks are the genetic material. Shedding water forms the shape of the land as flow boundary. A watershed is part of an encompassing cycle of water on land, oceanic water, and atmospheric water, so boundaries around these are arbitrary. Counting river water as a "resource" is colonial extractivism. River water flow connects in an upstream-downstream way, and there are consequences of our actions in both directions. Within the catchment, the plants and animals and the mineral, physical and chemical features entwine; producing soils (also living) from a perpetual interaction between vegetation, geology, microbes and climate. Once formed, erosion of soils and sediment deposition is continuous. Together these complex interactions give rivers a foundational purpose: to move water and sediment.

Rivers' functional voice then is to keep doing as they have done. Since their creation, they have evolved, adjusting and adapting to their surroundings; in a way, the 'ever-presence' is the constancy of these processes. Rivers respond locally to surprises they know are coming, what they receive from rainfall, from groundwater that leaks to the surface, and from upstream in their headwaters. A river's slope profile is 'graded'; it is a perfect response to what the river has received in the past, and in this way rivers have a memory of seasonal, yearly, decadal, centennial and millennial water flow events, events that have needed processing and to which they are adjusted. The dimensions of a river's channels - how wide and how deep - and the way a river slithers across the plains, depend on what the river is carrying, how much and when, and what it encounters along the way.

A river's mouth is ambiguous, a constant back and forth tussle among oceanic contribution and Land deliveries, growing and shrinking. In these ways, rivers respond to, and modify, their surroundings and conditions and they self-organise. The emergent properties of a river as a living system belong to the whole river; elements are interdependent and connected, therefore the purpose of a river is a function of the relationships that exist. In the case of water bodies, gravity, water, carbon, and other elements reinforce these filial links. There is a flow to this connectedness and relationality too - water and nutrients flow into and out of physical entities that make up life, a flow that makes up the essence or spirit of a greater whole. Humans are part of these living systems. Indigenous peoples' knowledge systems cherish and communicate enlivened rivers (Parlee, Berkes \& Gwich'in, 2005; Wooltorton, Collard \& Horwitz, 2019) and a river's spiritual entities create and continue to exist in landforms and lifeforms.

\section{Narratives for the Katitjiny Bidi: Regenerative knowing}

Having left our university libraries, our katitjiny bidi visits four storytellers with important narratives. We begin in Whadjuk Noongar Country, in Perth.

\section{Djenark of Derbal Yerrigan}

For over a year I walked with a small group of preschool-aged children, a graduate student, and three educators to explore and experiment with different ways children might walk-with, learn-with, and become-with Derbarl Yerrigan (see Walking-with Derbarl Yerrigan 2019). The Noongar name Derbarl Yerrigan describes the mixing of salt and fresh waters as the tidal ebb and flow, the breathing of the estuary that makes up this culturally, environmentally, and historically significant river in Whadjuk Noongar boodja (Country) (Bracknell, Collard, Palmer \& Revell, 2015). During our walks, we learn how to take time to pay attention to Derbarl Yerrigan's invitations. As a result, new, imperfect, and non-innocent relations were made between river, children, adults, plants, and animals. One of these relations included Djenark, silver gull (see Wintoneak \& Blaise, 2021) who invites us to think with colonial pastpresent histories. 
"Kwarwh,! Kwarwh! Kwarwh!"It's Kambarang, the season of birth and a warm change in weather and longer dry periods. Looking up and around the blue sky, Margaret spots Djenark and excitedly shouts, "Look! They are here....One, two! Here comes Djenark." Gliding with wind, circling above our heads, they land close to us on Derbarl Yerrigan's sandy shoreline. Stopping, and then crouching low, Margaret stretches her hand out slowly towards Djenark. They hop towards her, and she remains still. Then, leaning forward, Margaret reaches her hand further, with palm facing upwards. Djenark is watching Margaret........ "Kwarwh!" they call, and take off, circling in the sky above before flying away.

\section{Pre-colonial stories of Wadjemup (renamed Rottnest)}

"Sunset Dreaming" tells how significant the coast near Derbarl Yerrigan is to Noongar people. It states, " ... when a clan member dies the body is buried in the nearest coastal dunes or Dreaming trail” (DPIRD, 2011, p. 3). This is a reminder that walking-with Derbarl Yerrigan includes walking with past Noongar people, their spirits, in the present.

"Ten thousand years ago the sea level began to rise, flooded the coastal plain and isolated the islands. Beneath the waves now lie the graves of Noongar ancestors." Wadjemup, located 19 kilometres off the coast of Fremantle, is one of these islands, and it has a violent colonial history. From 1838-1931 Wadjemup was used as an Aboriginal prison island and forced labour camp.

"Sunset Dreaming" explains that Djenark represents the spirits of the dead. "As they fly each day between the coast and the islands, the seabirds maintain the spiritual link between Noongars buried on the mainland and those beneath the sea" (DPIRD, 2011, p. 3).

\section{Gathering of Souls: Sound mapping Djenark}

Commissioned to respond specifically to Djenark and Derbarl Yerrigan, audio-visual artist Cissi Tsang creates an audio-visual series, entitled Djenark (Silver Gull) based on Djenark and one of its habitats, Booriarup, as part of the exhibition, Feminist Responses to Climate Change. Through soundmapping, this series explores the spiritual and connected dimensions of Djenark using field recordings, music visualisation, audio processing, sonification, and vocals. One of the pieces, Gathering of Souls, uses an audiorecording of Djenark slowed down (x32) to consider the hidden depths and harmonies behind the calls, and how spirits might feel being transported to Derbarl Yerrigan. The slowed down and haunting calls are barely recognizable to the harsh, high-pitched 'kwarwh' that Margaret encountered while walking-with Derbarl Yerrigan. Accompanying this unfamiliar sound, is a data-responsive animation of Djenark movements. Wings, like the drawn out haunting calls, slowly move up, down, and across the screen, while lingering and dissipating. These slow and dissolving movements and sounds reconfigure time as co-becoming. Linear time is neither inclusive nor relational. Even though Djenark flies away, and we can no longer see or hear them, we are always in relation with them and the souls of ancestors over and under the waters, where people still walk along the river, as we always have and always will, now on our katitjiny bidi.

\section{Carers of the ngama, waterholes of the Great Western Woodlands}

As a facilitator, mentor and teacher, the journeys on Ngadju Country have shown me how much I can learn through observing children at play, as they float lightly over the rocky outcrops, peering into ngama (waterholes) as I let go of long held views of teaching children. Letting Ngadju children lead, learning from them on Country. This is their Country. They move in it without fear, knowing place. 
Vignette 1: What we don't know sets the scene

She talked of her mother, of her father, of the connection, through family to the area. We explained our intent. To take the students out for the day with scientists and poets to learn about the area and we wanted, hoped for, an Indigenous perspective. How could we not acknowledge the millennia of human life on these Lands?

She changed her mind. She went home to collate some artefacts and joined us at the water hole on the edge of town. A fence surrounded a big gouge in the laterite outcrop. The students crowd around. She picked up chips of carved rocks. She points out the area and talks of campfires and meeting places and water holes. She talks of ngama, settlers and dynamite. How this was once a traditional camping ground settlers came in looking for water and sealed its fate. She shows us the plaque that honours the settlers and gives reference to the traditional owners, but there is a spelling mistake. They did not consult Traditional Owners.

It sets the scene. The historical perspective is noted. We have another history, told simply, without emotion. However, the emotion is there and the teachers react with quiet consternation. They do not know this history and are unaware of the layering of these stories; in fact, layer upon layer if we scratch the surface.

Vignette 2: Grandson of a Waterhole Carer

There is a photo

Of him

At seven

Staring outward

Across the red earth

At what I don't know.

His grandfather was deep

Within him

Along with a sadness

Hurt

That needed no words

To feel

To understand.

He looked at the ngama

Once

Full of water

And said his Pop knew.

We listened, once

To an important Woman

Who added weight

To that story.

She talked of

Connection

And right way

And the children listened.

He listened. 
The ngama

Is dry now

Full of sand

As the heart is

Heavy.

The story unfolds

Over time

As we journey

And I (teacher) begin

To understand.

He points out the bus window

To the

Mountain

In the distance

Can you walk there, he asks.

I nod.

These are important places

To him

Now

And into

The future.

There are

Stories

He knows

Deep within.

\section{Recognising shimmer: Bilya, Collie River, Southwest Western Australia}

I am a woman who grew up in Noongar Country. On a regular basis, I walk along the wagyl bidi (serpent's trail) beside Bilya, the Collie River in Wilmen Noongar Country. Upon approaching Bilya, I always sing out to Ngangungudditj walgu, the hairy faced snake, as I've been taught to do by Noongar Elders (Northover, 2008; Wooltorton, Poelina \& Collard, 2021). I throw sand rubbed across my underarm into Bilya and in Noongar language I tell kin my name, that I have come to Bilya to pay my respects to Country, to care for Bilya and kin creatures, and because it makes me happy. It feels polite to do this, and it awakens my senses into an attentive awareness, into attuning more carefully than when I (for example) walk along the road or to the shops. I notice wagtails approaching me as I approach them, and kangaroos paying attention to me as I walk respectfully close by. I feel the wind and its impact on the creatures, the trees and on my skin. Wind sometimes whips up a frenzy, and brings the clouds, the cockatoos, the crickets and me into a wild conversation of sorts. At other times the wind remains silent, leaving me to attune to life around me, that is now holding my deep attention.

Bilya has multiple dams. It has been pumped, drained and polluted in various ways: a shadow of its former self. I saw the shimmer of life, radiance, ancestral power, on Bilya, one evening. It was just before sunset, and the river was still, reflective and communicative with multiple bird song. The shimmer seemed to move - the light formed like a rainbow above the river, but visible in each direction I turned my head. It was the last evening of that Collie visit, and I had sung out to Ngangungudditj walgu to let kin know I would be back next season. I feel connected to 
Bilya and committed to keep returning. I know too, that extinction cascades remove shimmer from the world (Bird Rose, 2017).

\section{Martuwarra time}

Nganyoo yimartuwarra marnin means, I am a woman who belongs to the Martuwarra, Fitzroy River, in the Kimberley region of Western Australia. Martuwarra is my identity, my spirit, my culture, my knowledge keeper, and importantly, an ancestral serpent being who created and holds the law (RiverOfLife et al., 2021). The law are the rules for everyday reciprocal living, regeneration and ethics of care and love. Nyikina people are taught to come from and belong to a world of we and not me (Redvers et al., 2020). Everything in a cycle of time, waiting time, as determined by Country.

My family and nation have lived with this River from the beginning of time. Nyikina people have always storied, laughed, cried, celebrated and shared ceremonies, dreams and songlines with their kin, ancestral serpent beings (RiverOfLife et al., 2021). Martuwarra nations are bound through a law of obligation to promote and protect Martuwarra's right to life, to live and flow (Lim, Poelina \& Bagnall, 2017).

Poelina describes how as an Indigenous person, her people learn from a very early age, to listen, think, feel, and to be always conscious of the environment, the seasons, the beings, our kin around us. The elders teach them to look up in the sky, down to the ground, to see their environment in its totality in cycles of time, waiting time - including the stars, the clouds, the wind, the rain, the spirits of place, bringing past, present and future into the now. When Martuwarra people are born into a totem group, in Nyikina language it is known as their jadiny (RiverOfLife, Poelina, Bagnall \& Lim, 2020). It can be an animal, plant or bird and Nyikina people learn how a non-human being can teach people to learn, hear and feel; through an ethics of care and love for all their kin (Poelina, 2021).

Living in a deep relationship with Country, with non-human kin is a lifelong environmental values and ethics-based educational process. Martuwarra people receive their First Law stories through their non-human kin, when they are ready to listen, when the 'time is right'. Martuwarra people connect through their 'liyan', to learn how to see, hear, and read Country. Through learning together, we share mutual obligation and respect, we self-regulate our behaviour to other human and non-humankind (Nangan \& Edwards, 1976; Poelina, Wooltorton, et al., 2020).

Martuwarra people and their non-human kin learn to live in and between time, a learning journey within cycles of time, forever time. It is deep because not only does this require time to look back, but it is forward looking, thinking and acting, bringing the future and the past into this long now, trusting the seasons, trusting our actions, so the future is not a surprise. Waiting time requires reflection, questions, and challenges, of self and others human and non-human within our environment. Living together as we and not me, means we consider every living being to be part of the whole environmental living system. Nobel Prize winner Ostrom (2009) recognises the value of Indigenous wisdom for managing our environment, which collectivises 'taking' from the 'commons' to ensure an enduring presence. Indigenous environmental stewardship balances and self-regulates, for the greater 'common good'.

\section{Discussion: Regenerative Futures}

We set out to answer several questions in this paper, the first one being how we extend our sense of society to include the agencies of non-human beings and places. In answer to this question, we learn to recognise ourselves within our local ecological family, as integral to shared Country and part of collective ancestries. We learn to pay close attention, to hear and see places, and recognise the messages of Country. Once we readjust our mind-sets, people-place stories are recognisable in 
plain sight and in everyday places. This also applies in built up places like cities. Grasses and birds might be present or close by. This way, we are response-able (have ability to respond) to invitations always present - to walk into the shallow waves at the river's edge as they lure us to take another step; to stop in our tracks and notice where the hawk lands, and to see the lizard walking across our path. Soon we recognise the synchronicities linking these events, and perhaps - after quite some time - we might notice an avian observer within the tree, and finally, perhaps, we might perceive some intentionality, drawing us 'further-towards'. This change of mind-set may not be easy for adults to undertake. Perhaps our habituation is to sink into our minds as we walk - sometimes wearing headphones for distraction. In this case, a mobile phone camera, or regular visual diary entries might help us to pay attention to our living surroundings, to re-inhabit our bodies, to create alternative experiences from the same routines and to sense the agency of our ecosystem relations in our sense of society.

We asked how we might understand the requests of our non-human kin in this reconceived polity, while taking the necessary time for co-becoming. This question calls up our sense of ourselves as having response-ability with our local ecosystems as part of our everyday. We continue to learn to build knowledge through being responsive-with our ecological community. To pay attention to Djenark when she calls, noticing the feathers kin leaves as hints of something beyond. To notice the shimmer, to recognise the depth of colours and feel the vibrations of joy. To care for the Ngama, as Ngama cares for kin through sharing and connection. To be conscious of our kin always around us - birds just outside of our reach, speaking messages through the leaves, waiting for understanding.

These stories and ways are ancient, always renewing, always inviting, always ready: remembered. The seasons change, as we notice our deepening engagement with our non-human kin who behave differently, who beckon us in different ways. Then, when our ecosystem relations recognise our readiness, we might hear the haunting call - or was it just the wind? We might feel the cold chill of a colonial chain - what caused that feeling? Perhaps these sensations will beckon us to a library, or a museum, or perhaps we might consult the Elder we regularly pass, after mentioning the curling breezes? We recognise our co-becoming with our ecos, as our storying sits into our places, and we see our same places differently. While our routines adapt with the changing weather, we understand ourselves within our place-communities, recognising past as continuous into our present.

We asked how this standpoint is reciprocal, regenerative, and restorative and how it can become embedded in the heart of Australian environmental education. To address this question, we contemplate a notion of waiting time.

\section{Waiting time - a temporal worldview}

Rivers, like Country, function in a seasonal way as active agents linking time and place, paradoxically being particles of energy, held together to create, mobilise and sometimes, transform living landscapes. Living, patterned, perpetual landscapes hold memory and offer instruction through plants and human/non-human beings of its living ecosystem. In the cycling of seasons, Country and Rivers bring together the past with the present to co-construct the future. The synthesis of time and place produces a temporal worldview that is inclusive of agential life-filled places. Culturally embedded knowledge systems articulate meanings in species and places, enabling comprehension of rivers and their stories, ceremonies and arts, in deep time, waiting time.

Ancient knowledge systems recognise great wisdom and authority in river systems, recognising and valuing spiritual entities who create and continue to exist in landforms and lifeforms. Kincentric ecosystems are relational and obligatory, and form the basis of First Law. First Law connects multispecies family members as kin with their places through kinship classifications. Young Indigenous leaders are taking this ancient wisdom, and making 
modern stories, to share how we can combine collective wisdom, for planetary wellbeing. For example please view, https://vimeo.com/519485101/e7dd271cec (Perdrisat \& Poelina, 2020). Through inter-generational transfer of these stories and close observation, non-human totems: perhaps a lizard, or a crocodile; teach children what it means to be human as they grow up. Kinship systems create forever culturally sanctioned family relationships between people, their Country and Rivers. All the while maintaining cultural explanations for ecological purposes in the protection of the 'commons for our common and greater good' (Ostrom, 2009). These reciprocal relationships are deeply responsive, as people have response-ability. Children grow into these kincentric ecosystems, learning responsiveness, reciprocity and reflexive awareness through human and more than human teachers.

In these ways, for cultural and scientific reasons, Country responds to the past - in the present - to co-exist in balance and harmony with their human kin. For Indigenous Australians, Country and people co-exist and co-create time. Entwined together, Country and people have created a symbiotic relationship to hold and transmit knowledge over time through Dreaming Country stories. Edwin Mulligan (2014), Nyikina Walmajarri man, through his poetry connects to this earth, sky and River Country. We invite readers to view: https:/vimeo.com/ $638357785 /$ be0fd7a5b5. We share and experience his ability as a special human being to connect through time to and with Country, in these ways, ecosystems are permanently embedded in and with people through inter-generational obligation.

In this temporal worldview, knowledge is always regenerating across the generations, allowing pastpresentfuture to flow through the generations, always co-becoming through responding to Country; always regenerating knowledge that is itself regenerative. Country - as Land and Rivers - are central relational players in this worldview, always inviting, responding, adjusting, participating, leaving messages, offering stories for the hearing, feeling, creating and engaging. In this worldview, of paying deep attention and being responsive, animals and plants teach us to be human. Our active participation within the law of the Land, finds meaning through waiting time. While waiting, new information and new secrets are waiting until the time is right for stories from deep time to emerge.

\section{Time in environmental education}

To embed this worldview in the heart of environmental education, we remember that by its presence or absence, inclusivity or exclusivity, all education is environmental education (Orr, 1994). In this article, while we have highlighted some relational qualities of time that link us with our ecosystems, we have foregrounded ecosystem engagement. Beginning with place-time relationships, we offer a starting place for real education. This transdisciplinary approach attends to the cross curriculum priorities of Sustainability and Aboriginal and Torres Strait Islander Histories and Cultures (Australian Curriculum, nd). Storying places with Elders is a way into both of these priorities. When we synthesise these priorities, we find that all education is environmental education, and that Aboriginal wisdom shows us we are part of; and integral to our environments ${ }^{5}$. Therefore, as teachers, parents and Elders, we engage Country with children and young people, because we learn by paying attention as our young people do. For us to see the shimmer, and respond to the invitations of the waves, we may need to learn with or from our young people. To hear the sounds of the souls djenark carries and feel the chill of the colonial chains that are tugging at a child and his family, we need to experience our ecosystems, our places and our stories.

Our stories are Australian stories. As long as we live, we need to continue to tell our stories to decolonise Australia. In this way, our children learn to engage and feel Country. As educators, we recognise that learning is reciprocal, place-based, relational and responsive. 
Kids on living country: waiting time

There is this

Waiting time

Listening to place

The wind's breath

The whispering trees

The plant in flower

The country

The calling

The rhythm!

The carpet python

As it reveals itself

On the road

And we stop

To watch

Kin whispering a story

to the senior woman

Creating bonds

Without ink and paper.

The dingo

That rests upon

Your back

As the stars look down

In the dark of night.

Or trots along

Beside your $4 \times 4$

As you journey across

Country

Listening.

It is the waiting time

The rhythm that calls

Shaping the journey

That shares place

And with it story

Of bobtail

That wanders

Across the road

Sharing the story

Of the flower

And the change of seasons

That connects us. 
It is the clouds

The smell as rain hits

The red earth

The shimmer

In the Woodland

It is not linear

This time

As place reveals itself

And stories unfold

It is country

Talking.

$* * *$

Learning on Country in cycles of time, waiting time means we need to make time, to be patient. We need to 'see with our ears and listen with our eyes' (McDuffie \& Poelina, 2018) to observe what secrets are revealed. We become observational and caring, and we wait for the signs. We learn from Indigenous people to strengthen our empathy of care and value all life, such as responding to an invitation issued by a mallee fowl while crossing the road to her nest in front of our busload of children. This is very do-able.

\section{Conclusion}

Australian environmental education may be the oldest on the planet. We have 65,000 years (Clarkson et al., 2017) of continuously living with Country, listening to Rivers, attentively watching and waiting. Children need time to develop their own learning relationship with Country. Spending time on Country builds familiarity, confidence, and empathy. Engaging cultural environmental landscapes opens children's minds to appreciate the depth and richness in the biodiversity, beauty of the landscape, and the wonders of nature.

In these regenerative times prompted by the Anthropocene, Aboriginal voices are situated to draw on ancient wisdom for local learning and to share information across the globe as ecological imperative for humanity. Furthermore, this means revealing the lived experiences, and relationships of people and place. It means acknowledging that climate-related problems, injustice, pandemics and poverty show that human and planetary ecological health are directly connected.

Country is an active witness in the lives of Indigenous peoples. We all have a responsibility to listen, to help create a new direction for the future. There is no other time - there is only now - where the past and present come together to shape the future. Its regeneration is optimistic and visionary; it is a long, challenging (but heart-warming) journey towards Healing Country. To identify with local Country, to know Country means to be part of environment.

It is time to open minds, to hear local storytellers, to engage with stories of deep history and the colonial experience. We suggest young children already have or easily relearn these values, skills and knowledge. They - and we - need regular engagement and practice. Let young people lead; let them learn; let them teach. Through this inter-generational approach, we continue to nurture lifelong 'both way' learning for young and old, Indigenous and non-Indigenous learnings, sharing values in an ethics-based environmental education.

In this paper postqualitative research foregrounds the sentient nature of life as ancestral power and brings the vitality of co-becoming as our places into active engagement. It enables coloniality to surface, and reveals how it sits in our places and lives, in plain sight but unnoticed because of its so-called common sense. Postqualitative research relates with ancient knowledges in foregrounding Country's animacy and presence, revealing the essence of time as non-linear, cyclical 
and perpetual. In this way we are our places, weather and climate, not separate. Postqualitative research also relates with ancient knowledge in illustrating Country as agentic and time as multiple, free of constraint and directly involved in our everyday. Country as Aboriginal philosophy is here always; a strong basis for decolonisation and planetary wellbeing.

Acknowledgements. None.

Competing Interests. The author(s) declare none.

Financial Support. This research received no specific grant from any funding agency, commercial, or not-for-profit sectors.

Conflicts of Interest. None.

\section{Endnotes}

1 In Western Australia where the authors live or come from, the preferred term for reference to Indigenous people is the name of the specific nation being referred to, or Aboriginal. In this article, we use the term that seems respectful.

2 Usually, NAIDOC Week is in July in Australia, to celebrate Aboriginal and Torres Strait Islander histories, cultures and achievements. See: https://www.naidoc.org.au/about/naidoc-week

3 In this paper Horwitz, Wooltorton, Muecke and White drafted the theoretical sections of the katitjin bidi, followed by Poelina, Blaise, Aniere and Wooltorton who produced vignettes and narratives while developing and applying theory. As a research group, we collaboratively analysed, synthesised and concluded the research.

4 Capitalization of Land and Country denotes an understanding of the terms as inclusive of place-based entanglements such as knowledges, spirit and their implicit connections. These local and Indigenous understandings are becoming universalized. 5 Otherwise, it is colonisation of young people's minds.

\section{References}

Australian Curriculum (nd). Cross-curriculum priorities. Retrieved from https://www.australiancurriculum.edu.au/ f-10-curriculum/cross-curriculum-priorities/

Barad, K. (2007). Meeting the universe halfway: Quantum physics and the entanglement of matter and meaning. Durham, USA; London, UK: Duke University Press.

Barad, K., \& Gandorfer, D. (2021). Political desirings: Yearnings for mattering (,) differently. Theory \& Event, 24(1), 14-66. Bignall, S., Hemming, S., \& Rigney, D. (2016). Three ecosophies for the anthropocene: Environmental governance, continental posthumanism and indigenous expressivism. Deleuze Studies, 10(4), 455-478. DOI 10.3366/dls.2016.0239.

Bird Rose, D. (2017). Shimmer: When all you love is being trashed. In A. Tsing, H. Swanson, E. Gan \& N. Bubandt (Eds.), Arts of living on a damaged planet (pp. 51-63). Minneapolis, London: University of Minnesota Press.

Bracknell, C., Collard, L., Palmer, D., \& Revell, G. (2015). Ngatj baranginy ngulluckiny koorliny Derbal Yirigan bilya: Take me to the place the estuary that place on the river that rises and falls. In J. Bolleter (Eds.), Take me to the River: The story of Perth's Foreshore. Perth: UWA Press.

Buchanan, B., Bastian, M., \& Chrulew, M. (2018). Introduction: Field philosophy and other experiments. Parallax, 24(4), 383-391. DOI 10.1080/13534645.2018.1546715.

Chakrabarty, D. (2007). Provincializing Europe: Postcolonial thought and historical difference. Princeton: Princeton University Press.

Clarkson, C., Jacobs, Z., Marwick, B., Fullagar, R., Wallis, L., Smith, M., \& Pardoe, C. (2017). Human occupation of northern Australia by 65,000 years ago. Nature, 547(7663), 306-306. DOI 10.1038/nature22968.

Díaz, S., Settele, J., Brondízio, E., Ngo, H.T., Guèze, M., Agard, J., \& Zayas, C. (2019). Summary for policymakers of the global assessment report on biodiversity and ecosystem services - unedited advance version. Retrieved from https://www. ipbes.net/system/tdf/spm_global_unedited_advance.pdf?file=1\&type=node\&id=35245

Francis, Pope (2015). Encyclical letter: Laudato Si' of the Holy Father Francis - on care for our common home. Retrieved from http://www.vatican.va/content/dam/francesco/pdf/encyclicals/documents/papa-francesco_20150524_enciclica-laudato-si_ en.pdf

Graham, M. (2008). Some thoughts about the philosophical underpinnings of Aboriginal worldviews. Australian Humanities, 45, 181-194. Retrieved from http://press-files.anu.edu.au/downloads/press/p38881/pdf/eco04.pdf

Graham, M. (2014). Aboriginal notions of relationality and positionalism: A reply to Weber. Global Discourse, 4(1), 17-22. DOI $10.1080 / 23269995.2014 .895931$.

Jenkins, A., Horwitz, P., \& Arabena, K. (2018). My island home: Place-based integration of conservation and public health in Oceania. Environmental Conservation, 45(2), 125-136. DOI 10.1017/S0376892918000061. 
Kimmerer, R.W. (2017). Speaking of nature: Finding language that affirms our kinship with the natural world. Orion Magazine(March/April). Retrieved from https:/orionmagazine.org/article/speaking-of-nature/

Lim, M., Poelina, A., \& Bagnall, D. (2017). Can the Fitzroy River Declaration ensure the realisation of the First Laws of the River and secure sustainable and equitable futures for the West Kimberley? Australian Environment Review, 32(1), 18-24.

McDuffie, M., \& Poelina, A. (2018). Nyikina collaborative filmmaking in the Kimberley: 'learning to listen with your eyes, and see with your ears'. In P. Morrissey \& C. Healy (Eds.), Reading the country: 30 years on. Sydney: University of Technology, Sydney.

RiverOfLife Martuwarra, McDuffie, M., \& Poelina, A. (2020). Martuwarra country: A historical perspective (1838-present). Retrieved from https://researchonline.nd.edu.au/nulungu_research/5/

Milgin, A., Nardea, L., Grey, H., Laborde, S., \& Jackson, S. (2020). Sustainability crises are crises of relationship: Learning from Nyikina ecology and ethics. People and Nature, 2020(2), 1210-1222. DOI 10.1002/pan3.10149.

Morphy, H. (1989). From dull to brilliant: The aesthetics of spiritual power among the Yolngu. Man (London), 24(1), 21-40. DOI $10.2307 / 2802545$.

Morrissey, P. (2019). The Muecke/Roe relationship as a model for Australian indigenous studies. In P. Morrissey \& C. Healy (Eds.), Reading the country: 30 Years on (pp. 102-113). Retrieved from http://library.oapen.org/handle/20.500.12657/39711

Muecke, S., \& Roe, P. (2020). The children's country: Creation of a Goolarabooloo future in North-West Australia. London: Rowman \& Littlefield Publishers.

Mueller, M.L. (2017). Being salmon, being human: Encountering the wild in us and us in the wild. White River Junction, Vermont: Chelsea Green Publishing.

Mulligan, E. L. (2014). Dreaming country. In Poelina, A, Perdrisat, I, Mulligan, R, Mulligan, G, Mulligan, E, Warbie, J, \& McDuffie, M (Eds.), Warlangkooroo-Kandarra: Stories of Noonkanbah country. [DVD]. Australia: Madjulla Inc. https:// vimeo.com/638357785/be0fd7a5b5

Nangan, J., \& Edwards, H. (1976). Joe Nangan's dreaming: Aboriginal legends of the north-west. West Melbourne, VIC: T. Nelson Australia.

Northover, J. (2008). Joe Northover talks about Minningup Pool on the Collie River. Retrieved from https://www. noongarculture.org.au/joe-northover-minningup-pool/

Orr, D.W. (1994). Earth in mind: On education, environment, and the human prospect. Washington, DC: Island Press.

Ostrom, E. (2009). Beyond markets and states: Polycentric governance of complex economic systems. Paper presented at the Nobel Prize Lecture, Stockholm. https:/www.nobelprize.org/prizes/economic-sciences/2009/ostrom/lecture/

Parlee, B., Berkes, F., \& Gwich'in, T.i (2005). Health of the land, health of the people: A case study on Gwich'in berry harvesting in Northern Canada. EcoHealth, 2(2), 127-137. DOI 10.1007/s10393-005-3870-z.

Perdrisat, M., \& Poelina, A. (2020). First law in planetary health. Retrieved from https://vimeo.com/519485101/e7dd271cec

Poelina, A. (2021). Martuwarra First Law Multi-Species Justice Declaration of Interdependence: Wellbeing of Land, Living Waters, and Indigenous Australian People. Doctor of Philosophy (Health Sciences). University of Notre Dame Australia, Fremantle.

Poelina, A., Brueckner, M., \& McDuffie, M. (2020). For the greater good? Questioning the social licence of extractive-led development in Western Australia's Martuwarra Fitzroy River region. The Extractive Industries and Society. 10.1016/j.exis. 2020.10.010.

Poelina, A., Wooltorton, S., Harben, S., Collard, L., Horwitz, P., \& Palmer, D. (2020). Feeling and hearing country. PAN: Philosophy Activism Nature, 15, 6-15. Retrieved from http://panjournal.net/issues/15

Redvers, N., Poelina, A., Schultz, C., Kobei, D.M., Githaiga, C., Perdrisat, M., \& Blondin, B.S. (2020). Indigenous natural and first law in planetary health. Challenges, 11, 29. DOI 10.3390/challe11020029.

Riley, K., \& White, P. (2019). Attuning-with', affect, and assemblages of relations in a transdisciplinary environmental education. Australian Journal of Environmental Education, 35(3), 262-272. DOI 10.1017/aee.2019.30.

RiverOfLife, M., Poelina, A., Bagnall, D., \& Lim, M. (2020). Recognizing the Martuwarra's first law right to life as a living ancestral being. Transnational Environmental Law, 9(3), 541-568. DOI 10.1017/S2047102520000163.

RiverOfLife, M., Taylor, K.S., \& Poelina, A. (2021). Living Waters, Law First: Nyikina and Mangala water governance in the Kimberley, Western Australia. Australasian Journal of Water Resources, 25(1), 40-56. DOI 10.1080/13241583.2021. 1880538.

Stengers, I. (2010). Cosmopolitics 1. Translated by Robert Bononno. Minneapolis: University of Minnesota Press.

Bawaka Country, Suchet-Pearson, S., Wright, S., Lloyd, K., Tofa, M., Sweeney, J., \& Maymuru, D. (2019). Gon Gurtha: Enacting response-abilities as situated co-becoming. Environment and Planning D: Society and Space, 37(4), 682-702. DOI $10.1177 / 0263775818799749$.

Tollefson, J. (2020). Why deforestation and extinctions make pandemics more likely. Nature, 584(7820), 175-176. DOI 10.1038/d41586-020-02341-1.

van Dooren, T. (2018). Thinking with crows: (Re)doing philosophy in the field. Parallax, 24(4), 439-448. DOI 10.1080/ 13534645.2018.1546722.

Wahl, D.C. (2016). Designing regenerative cultures. Axminister, UK: Triarchy Press. 
Whyte, K.P. (2018). Indigenous science (fiction) for the Anthropocene: Ancestral dystopias and fantasies of climate change crises. Environment and Planning E: Nature and Space, 1(1-2), 224-242. DOI 10.1177/2514848618777621.

Williams, L. (2019). Reshaping colonial subjectivities through the language of the land. Ecopsychology, 11(3), 174-181. DOI 10.1089/eco.2018.0077.

Wintoneak, V., \& Blaise, M. (2021). Voicing Derbarl Yerrigan as a feminist anti-colonial methodology. River Research and Applications, 6(2), 77. DOI 10.1002/rra.3822.

Wooltorton, S., Collard, L., \& Horwitz, P. (2019). Living water: Groundwater and wetlands in Gnangara, Noongar boodjar. PAN: Philosophy, Activism, Nature, 14, 5-23. Retrieved from http://panjournal.net/

Wooltorton, S., Poelina, A., \& Collard, L. (2021). River relationships: For the love of rivers. River Research and Applications, Special Issue: Voicing Rivers, 15(2), 44. DOI 10.1002/rra.3854.

Bawaka Country, Wright, S., Suchet-Pearson, S., Lloyd, K., Burarrwanga, L., Ganambarr, R., \& Maymuru, D. (2020). Gathering of the clouds: Attending to Indigenous understandings of time and climate through songspirals. Geoforum, 108, 295-304. DOI 10.1016/j.geoforum.2019.05.017.

Bawaka Country, Wright, S., Suchet-Pearson, S., Lloyd, K., Burarrwanga, L., Ganambarr, R., \& Sweeney, J. (2016). Co-becoming Bawaka: Towards a relational understanding of place/space. Progress in Human Geography, 40(4), 455-475. DOI 10.1177/0309132515589437.

DPIRD. (2011). Sunset dreaming. In Aboriginal coastal use. Retrieved November 3, 2021 from http://beachcombers-kit.fish. wa.gov.au/wp-content/uploads/2011/03/Aboriginal-Coastal-Uses.pdf.

Gay'wu Group of Women (2019). Songspirals: Sharing women's wisdom of country through songlines. Australia: Allen \& Unwin.

IPCC (2021). Climate change 2021: The physical science basis. Contribution of Working Group 1 to the sixth assessment report of the Intergovernmental Panel on Climate Change. Cambridge: Cambridge University Press.

United Nations (2011). United Nations Declaration on the Rights of Indigenous Peoples. Human Rights Quarterly, 33(3), 909-921. DOI 10.1353/hrq.2011.0040.

Professor Anne Poelina is a Nyikina Warrwa Indigenous leader, human and earth rights advocate, filmmaker and a respected academic researcher. In 2017, she was awarded a Laureate from the Women's World Summit Foundation (Geneva), and is Professor and Senior Research Fellow with Notre Dame University. She holds membership to national and global Think Tanks. Professor Poelina is a Visiting Fellow with the Crawford School of Public Policy at the Australian National University, Water Justice Hub, to focus on Indigenous Water Valuation and Resilient Decision-making. See web site: www.martuwarrafitzroyriver.org; and www.majala.com.au. Email: anne@majala.com.au. Orcid ID: 0000-0001-6461-7681.

Assoc. Professor Sandra Wooltorton is from Noongar Boodjar, also known as southwest Western Australia, and is Senior Research Fellow at the Nulungu Research Institute at the University of Notre Dame Australia, in Yawuru Country in the Western Australian Kimberley. She is a geographer, educator and transdisciplinary researcher with interests in environmental humanities. Recent collaborative articles are Feeling and Hearing Country (2019); Hearing, Voicing and Healing: Rivers as Culturally Located and Connected (2021); The Land Still Speaks: Ni, Katitj (2017) and River Relationships: For the Love of Rivers (2021). She co-edited the Voicing Rivers Special Issue of River Research and Applications. Email: Sandra.wooltorton@ nd.edu.au. Orcid ID: 0000-0001-8677-870X

Professor Pierre Horwitz is Professor of Environmental Sciences, and Co-Director of the Strategic Research Centre for People, Place, \& Planet, at Edith Cowan University, Australia. He is recognised for his work on ecosystem approaches to human health, and as a theme coordinator for wetlands and health for the Ramsar Convention (2009-2015). He is currently the Co-Editor-in-Chief for the journal PLOS Water. Email: P.Horwitz@ecu.edu.au. Orcid ID: 0000-0002-8689-7888

Professor Stephen Muecke is Adjunct Professor at the Nulungu Research Institute Notre Dame University, Broome, an Emeritus Professor of Ethnography at the University of New South Wales, and a Fellow of the Australian Academy of the Humanities. Recent books are Latour and the Humanities, edited with Rita Felski, Johns Hopkins University Press, 2020 and The Children's Country: Creation of a Goolarabooloo Future in North-West Australia, co-authored with Paddy Roe, Rowman and Littlefield International, 2020. His most recent book is a translation of Vinciane Despret: Our Grateful Dead: Stories of Those Left behind, University of Minnesota Press, 2021. Email: S.Muecke@unsw.edu.au. Orcid ID: 0000-0003-1634-8637

Catrina Luz Aniere is CEO - Millennium Kids Inc., a not-for-profit environmental youth program which operates in Western Australia with partnerships across Australia and Indonesia. She has more than 30 years of international and Australian experience in the areas of program development and education for sustainability with a focus on children and youth directed initiatives. All Catrina’s work uses youth voice and engagement at its core. Email: catrina@millenniumkids.com.au. 
Professor Mindy Blaise is a Vice Chancellor's Professorial Research Fellow, in the School of Education, Edith Cowan University, Perth, Western Australia. She is also Co-director of the Centre for People, Place \& Planet and Co-founder of the Common Worlds Research Collective. Her transdisciplinary and postdevelopmental research with the more-than-human uses responsive, affect-focused and creative methods to rework a humanist ontology. She is interested in how the more-than-human and feminist speculative research practices activate new meanings about childhood that sit outside the narrow confines of developmentalism. Email: M.Blaise@ecu.edu.au. Orcid ID: 0000-0003-2476-9407

Dr Peta White is a senior lecturer in science and environmental education at Deakin University. She educated in classrooms, coordinated programs, supported curriculum reform and prepared teachers in several jurisdictions across Canada and Australia. Her $\mathrm{PhD}$ explored learning to live sustainably as a platform to educate future teachers. Peta continues her commitment to initial teacher education leading courses, units and programs and in-service teacher education through research-informed professional learning programs. She was recently acknowledged as a Senior HEA Fellow. Peta's current research follows three narratives: science and biology education; sustainability, environmental and climate change education; and collaborative/activist methodology and research. Email: peta.white@deakin.edu.au. Orcid ID: 0000-0002-0225-5934.

Cite this article: Poelina, A., Wooltorton, S., Blaise, M., Aniere, C.L., Horwitz, P., White, P.J., \& Muecke, S. (2022). Regeneration time: ancient wisdom for planetary wellbeing. Australian Journal of Environmental Education 38, 397-414. https://doi.org/10.1017/aee.2021.34 